\title{
Moving into the neighbourhood: embodiment, sacrament and ritual in urban mission
}

\author{
Hannah Bucke
}

The Revd Hannah Bucke is a Methodist presbyter pioneering a new ministry in a large town centre. She lives in Essex with her husband.

hannah.bucke@methodist.org.uk

Southend-on-Sea, UK

This article aims to explore the significance of embodiment, sacrament and ritual in urban pioneer ministry. Stemming from early experiences working within this context and from a particular experience of using installation art to help engage those outside the Church with its rituals and stories, I argue for the importance of the embodied experience within a particular place as a means of engagement. The literature surveyed makes the case for a broad understanding of the sacramental in which all material things have sacramental potential. The differing influences of theology and social anthropology upon the literature offer distinct perspectives on the drawing of boundaries in relation to sacrament and ritual, and on how meaning is made from experience in the light of prior knowledge and understanding of the Christian tradition.

EMBODIMENT • ENCOUNTER • MISSION • RITUAL • PIONEERING • SACRAMENT $\bullet$ URBAN 


\section{Beginnings}

What have I done? Will anybody come? The first hour is a very lonely hour, plenty of time to think about what I have done and about how I got here, because nobody does come. It is 10am on Palm Sunday and I am sitting alone in a unit of The Royals Shopping Centre, Southend-on-Sea. ${ }^{1}$ Yesterday morning the unit was empty, one of several empty shops in town, a sign of the economic climate. Today it contains seven installations themed around the Easter story, a sign of something very different. They would be called 'prayer stations' if this was a church but 'installations' is far less threatening for a shopping centre.

'Easter Icons: a Pop-Up Installation' is an ecumenical project, a creative collaboration between Baptists and Methodists, others from various other local churches who are helping to staff it, but the rest of the team will be in their respective churches this morning. In a sense I am in mine. I am the town-centre minister, 'for all of us' a Baptist colleague says. I am the project leader for'Easter Icons', the one who built the relationships, made the connections in the town, and brought the Christian story to the shopping centre for Holy Week. So I am the one sitting here, alone, feeling vulnerable, waiting for someone to come.

If they do come, what will they make of this attempt to tell the Easter story for today? Will it mean anything to them? Will they post a prayer in the Temple wall installation and reflect upon the fickle nature of celebrity at the Palm Sunday installation? Will they write down a beautiful act they would like to be remembered for and use the scented hand lotion at the anointing installation? Will they take bread and grape juice from the Last Supper installation, remember a betrayal at '30 Pieces of Silver'? And will the experience be anything more than a ten-minute distraction from their shopping trip?

People do come. A trickle on the first day but it seems to gain momentum over the course of the week and over 650 people have come by the time we close on Holy Saturday. Nearly 300 prayers have been posted in the wall. A second book has been bought to accommodate the beautiful acts people wanted to record. Around 70 glasses of grape juice are consumed.

Of course the numbers do not say much. I do not really know what people thought, what people experienced, whether it helped unchurched people connect with the Easter story, at least for the most part. But there are some glimpses as I sit and watch people come and go during the week. The churchgoing Christians are easy to spot. Some have come especially to see this new initiative. They walk in confidently, follow the numbered stations 
confidently, write their prayers, their beautiful acts, and take the bread and grape juice confidently. They know what to do. Other people are less confident. They hang around the door looking in - this is not a normal shop, not what they are expecting in their shopping centre. Some never make it inside, some walk past several times before venturing in. They ask'What is it?"What do I do?'

The woman from the coffee shop comes to bring me coffee. I encourage her to have a look around but she is already visibly moved by the atmosphere created by the music, lighting and the more striking sculptural installations. She is not religious, she has told me. One of the Street Rangers who patrols the High Street comes in to have a look. She writes a prayer. She is not religious. An elderly man takes his time at all the stations and then comes back to me on his way out, one of the few who offers feedback: he enjoyed it very much, very interesting, very thought-provoking. He tells me he is an atheist. I am glad these people have come - this is for them.

By the end of the week I have become very attuned to body language. I am particularly intrigued by the response to the sacrament-like ${ }^{2}$ installation, which invites people to eat bread and drink grape juice. Three of the seven installations ask people to actively participate and many do. Yet it appears that people feel more comfortable writing a prayer, adding to the book of beautiful acts and using the hand lotion, than taking bread and wine. Even though the instruction for the installation explicitly invites people to eat and drink from the table as a symbol of Jesus' last meal with his friends, most do not and some of those who do ask permission first from one of the staff. There are undoubtedly various reasons for this but it appears to me that this particular act of eating and drinking has some kind of special significance, whether positive or negative, such that most people do not perceive this act in the same way as the other acts, and so do not participate. For some the act of taking something into their bodies may be too intimate, for others there may be hangups about food or questions about the consequences of where this act might lead, for others still a sense that they might not be 'allowed', and a few seek further permission from me or one of the volunteers to partake, from another perceived to be 'in authority' perhaps.

We have created these installations, making space for prayer and something sacrament-like, for encounter with the Christian story in a shopping centre, because most people do not come to church. Mainstream denominations in the UK have experienced a significant decline in attendance since the beginning of the twentieth century. ${ }^{3}$ The 2011 Census reported a decline in 
those who identify themselves as Christian, down from 71.1 per cent in 2001 to 59.3 per cent in $2011 .{ }^{4}$ Church membership is much lower at only 11.2 per cent in 2010. ${ }^{5}$ This issue is particularly pertinent for The Methodist Church in Britain, which has thus far failed to stem a period of significant decline, losing 32 per cent of its members in the past 10 years. ${ }^{6}$

Perhaps none of this is surprising. These are times characterised by a distrust of institutions and authority, of metanarratives and claims to universal truth, times in which the individual takes precedence over the corporate. Professor of sociology Zygmunt Bauman describes what is often named 'postmodernity' as 'liquid modernity' in his book of the same title. ${ }^{7}$ This liquid modernity is a fast-moving, shape-shifting society of 'continuous change,', an 'individualized, privatized version of modernity. ${ }^{\prime}$ These are not the characteristics of the Church. There is a disconnect between church and society in Western society, a loss of shared language that runs deeper than people not knowing their Bible stories. The need to rediscover a common language seems a vital endeavour if church and society are to reconnect.

This need for church and society to reconnect is where I perceive the focus of my ministry to be. I am a Methodist presbyter pioneering a ministry of word and sacrament in the town centre. The Methodist Church has been absent from the town for over 20 years: the circuit closed its last town-centre church in the 1990s, leaving the area of densest population and highest deprivation in favour of a largely suburban presence. As I begin my ministry there is no Methodist congregation who gathers to worship here, no building to invite people to. I am stripped of conventional ministerial or ecclesial context. There is only one way for me to be 'in the neighbourhood': ${ }^{10}$ incarnationally, in the flesh. Sitting in the shop on the first morning of 'Easter Icons' was not the first time I have felt vulnerable.

On my first day as the town-centre minister I sit on a bench at the top of the High Street. I have put on my clerical collar with jeans and a parka - the uniform of my vocation worn with the uniform of the street, of everyone from rough sleeper to student to shopper. I wonder what I have done, what I am doing here, but mostly I wonder what I should do now. How on earth do I build a ministry here? Where do I start? What is my common ground with these people, who do not necessarily share my faith commitments? The answer seemed to be small and insignificant: I am here. 


\section{Interpretations}

'Being here' is perhaps an obvious starting point for a Methodist minister. The Methodist Church has its roots in the Evangelical Revival of the eighteenth century and in reaching unchurched people by finding new ways of communicating with them effectively, John Wesley himself preaching in the open air. ${ }^{11}$ However, I understand my 'being here' to be more than an outreach tool, used to encounter people so that they might be persuaded into church. It has become a defining principle as I seek to offer sustained presbyteral ministry in the world. Being here in the flesh, walking, listening, talking, praying on the street means that face-to-face encounters happen, conversations occur, relationships are built. It is how 'Easter Icons' came to be. This incarnational ministry of 'being here' has brought exciting possibilities and feels instinctively counter-cultural, not just in the church here in Southend-on-Sea, in its mainly attractional form, but in society too.

Philosopher Martin Heidegger suggests that technology has made global travel and communication faster than ever so that 'time and space are shrinking'. ${ }^{12}$ The result of this 'unsettles and terrifies' because we are no longer 'earthed', our ability to be anywhere effectively meaning that we connect with nowhere. ${ }^{13}$ Anglican bishop John Inge cites Heidegger's concept of dasein in A Christian Theology of Place, ${ }^{14}$ in which a person being in a particular place is significant: 'Throughout Heidegger's characterisation of person-in-world is a sense of immersion and inextricable togetherness rooted in time and space. ${ }^{\prime 15}$ Dasein therefore has both an ontological and geographical dimension. In recognising the importance of our placed-ness in the world to our sense of self and our experience of the world, Heidegger rejects the Aristotelian notion of place as an 'inert container' in which any geographical location can be the location for bodies and things; rather our surroundings resonate with ourselves and are intrinsic to the embodied experience. ${ }^{16}$

My experience of 'being' a minister of word and sacrament in Southend-onSea, with nothing more than my embodied self as a point of connection with others, is worthy of significant exploration and reflection. From my own experience of dasein I have encountered and related to the grieving woman who cries in front of me, the heroin addict whose broken body sleeps where I park my car, the woman who smiles and serves me coffee through her untreated depression. They are all here too, experiencing this place as embodied selves. This common experience of being embodied has a central place in the Christian faith, which stands in opposition to notions of spirituality 
divorced from the body and the material world, notions rooted in the dualism of Platonic thought. The importance of embodiment to the Christian faith also challenges the contemporary phenomenon of 'excarnation',17 in which technology in particular appears to make the virtual experience a substitute for embodied experience.

In recognising the value of the experience and particularly embodied experience, it is appropriate that I consider my own faith journey as a text worthy of reflection and influential to my ministerial practice. Significant to my understanding of God and of the human/divine relationship is a personal divine encounter of my own with both physical and emotional dimensions. I trace from this moment, which I would identify as an experience of the Holy Spirit, a dramatic shift in the way in which I relate to God. Prior to this event, my understating of God was grounded largely in an intellectual appreciation of the teachings of Jesus as those most conducive to a just society and of Jesus' life as a model for right living. The shift was from a commitment of the mind outworked through behaviour in the world to a sense of relationship with God in which my whole self could know God intimately. As significant as the moment of encounter itself, which I can pinpoint in time and place, has been its ongoing effects within daily life: I am now conscious of the potential to encounter God in every moment and of the divine presence in the everyday.

Seeking to understand my experience further, the concept of poiesis offers a useful insight. Academic practical theologian Heather Walton, drawing on the work of Marxist philosopher and sociologist Henri Lefebvre and Jesuit theologian Michel de Certeau, describes poiesis as 'the supreme, restless, transformative capacity of human beings to reshape their world and create meaning out of the mundane.. ${ }^{18}$ As well as making the ordinary and everyday the location for the extraordinary, this meaning-making on the part of the individual implies an active, participatory role in interpreting experience. We are not 'passive consumers' indoctrinated into understanding lived experience in particular ways. Rather we are the makers of meaning in our own lives: 'our world making is not a dreary matter of programmed instrumental action in pursuit of clear goals. It is integral to our being in the world and involves "love, sensuality and the body".20 This latter point gives validity to the richness of embodied experience over the narrowness of an exclusively intellectual approach to the meaning-making process.

In the light of my experience of faith and of my context for ministry, the remainder of this article will explore embodiment, the material and the 
sacramental as a means for encountering the divine. Much of the literature I have drawn upon takes a broad view of the sacramental, regarding the whole universe as a potentially sacramental place.

\section{A world of potential}

Baptist professor of systematic theology Paul Fiddes offers a useful overview of issues relating to embodiment, the material and sacramentality in his seeking to create a pastoral doctrine of the Trinity. ${ }^{21}$ Through dialogue between the doctrine of the Trinity and pastoral theology, Fiddes argues that all encounter must be bodily encounter, even in a world of virtual communication and relationships, because experiences in the mind cannot be separated from the reality of living an embodied existence. ${ }^{22}$ This leads Fiddes to the premise that if 'encounter' and 'body' are indivisible, and personal encounter with God is possible, then we must be able to speak of God as having a body. Such a view ensures that we avoid imagining the God in whose image we are created and with whom we may enter relationship, as something entirely 'other' than ourselves. Reinforcing this understanding of God as in intimate relationship with humanity is the Incarnation, the divine and human made inseparable in the person of Jesus, through which human bodies may become part of the body of Christ. It is the Christian understanding of God as having assumed human form that provides the mechanism for other embodied selves to participate in the divine.

Citing professor of theology and eco-feminist Sallie McFague's argument that the universe itself may be regarded as the 'body of God', ${ }^{23}$ Fiddes explores the idea of the world as a sacramental place in which all creation is a potential meeting place between God and humanity. Fiddes is clear that this concept of the sacramental is not centred on the nature or substance of any one thing but rather on the dynamic relationship which flows between them: the 'earthly stuff' becomes 'doors into the dance of perichoresis in God'. ${ }^{24}$ This view avoids associating God with actually being or becoming any particular matter in favour of an emphasis on the encounter and relationship that can occur through the material world, in which God's work as creator and sustainer may be revealed to those open to perceive it.

Fiddes explores McFague's argument for a sacramental theology that begins in the universal presence of God in the whole created order and moves to an understanding of the particular presence of God in Christ. This understanding 
reflects McFague's eco-feminist theology in which the denigration of non-male and non-human bodies in both historical and contemporary Christianity is problematic. However, while acknowledging the validity of this, Fiddes favours a view of the Incarnation as the paradigm for a sacramental world because of the 'unique depth of participation' of the Father and the Son in which the 'divine and human "yes" to the Father were one voice'. ${ }^{25}$ According to Fiddes it is only from the direction of the particular of Christ to the universal of the whole created order that all matter holds the potential to become sacramental.

Ultimately, in spite of the differing directions from which they approach the sacramental, Fiddes and McFague concur that God must be understood as being in some way embodied and that this opens up possibilities for the sacramental in all of life. It is from this context that Fiddes moves to explore the intriguing possibility, put forward by Austin Farrer, that the Christian minister might be regarded as 'a walking sacrament'. ${ }^{26}$ Emphasising the particular nature of ministry as a blurring of 'person and function ... being and doing', ${ }^{27}$ ministers embody a way of living and a set of values, and so can be understood as symbols of the ministry and person of Christ. Fiddes recognises the associated concerns, pointing out resistance to such an understanding because of the risk of elevating the status of the minister, leading him to emphasise the very ordinariness in which sacrament is rooted. Here Fiddes begins to tease out the distinction between the embodiment of something other than the self, and the nature of the self, reminding us again of the importance of the dynamic and relational aspects of the divine: the meeting rather than the place of meeting is significant.

Fiddes' linking of the embodied, the material and the sacramental offers a fruitful starting point as I explore a ministry with a sacramental dimension, focused in my 'being here'. The questions 'Where is my body?' and 'What is my body doing?' are a constant as I reflect upon my role in the town centre. I recognise, though not entirely comfortably, the sacramental nature of myselfas-minister, in which simply 'being' in the town is a deliberate representation of Christ's ministry in the world. The wearing of a clerical collar in this context has the potential to act as a reminder and a sign of the divine. By, for example, choosing to sit on the pavement with rough sleepers I understand myself to be engaged in an act in which the representative role l embody enables me to become a potential place of encounter with the divine.

Taking Fiddes' argument that it is the particular person of Christ from whom all things may derive their sacramentality, it follows that some understanding 
of the Christian story, particularly of the Incarnation and the Passion narrative, are an essential precursor to any perception of the world as a sacramental place and any experience of the divine through it. This question of how God is perceived and who may perceive God is explored further by Anglican bishop John Inge.

Writing in A Christian Theology of Place, ${ }^{28}$ Inge explores many of the same concepts as Fiddes in relation to the world as a potentially sacramental place and places the person of Christ as the locus for this. Inge identifies Christ the Sacrament of the Encounter with God by Roman Catholic theologian Edward Schillibeeckx as a key text in the twentieth-century development of sacramental thinking. ${ }^{29}$ From it stems the idea of the Incarnation as the foundation for understanding the sacramental as well as ideas of extending the sacramental out from particular sacramental rites to a much wider understanding. ${ }^{30}$ Inge also quotes professor of divinity and feminist theologian Ann Loades on the nature of the sacrament as about the 'saving union' rather than the substance of the elements themselves, ${ }^{31}$ an interpretation that resonates with Fiddes' relational and participatory understanding of sacrament.

In common with Fiddes, Inge points to the world, particularly the natural world, as a place of revelation with sacramental potential. Here Inge also highlights the concept of the world as God's body, though through a much earlier example than McFague's work: that of seventeenth-century Anglican theologian Thomas Traherne. ${ }^{32}$ Having laid the ground-work for a broad understanding of what is potentially sacramental, Inge goes on to ask a fundamental question: 'How are we to decide which things are behaving sacramentally, and when?'33 While Inge regards the world as full of possibilities for the sacramental, he argues for defining qualities that limit this to particular 'events', events which are 'rents in the opacity of history where God's concrete engagement to change the world becomes visible'. ${ }^{34}$ This means that sacramentality can be seen as having not only a material dimension but spatial and temporal dimensions also; it is an event in time and space.

In conceiving of sacrament as 'event', Inge then goes on to cite a number of pieces of research into such possible sacramental events which suggest that they are not unusual, tracing the work of William James in the late nineteenth century, through Alister Hardy in the mid-twentieth century and up to the work of David Hay, whose national survey in Britain in the 1990s found over a half of adults believed they had experienced a sacramental encounter of some kind. ${ }^{35}$ Significant in this research is not simply the numbers of people reporting such 
encounters but the importance of their locating such encounters in time and place, and not necessarily in 'holy places' such as churches: one of the descriptions Inge quotes is of an experience at Sea World, Florida. ${ }^{36}$

However, despite this concession to the 'artificial' as opposed to the 'natural' world as a possible meeting place with God, it would be fair to conclude that Inge, along with other writers with a broad understanding of the sacramental, places particular emphasis on the 'natural' and the 'holy' locations as most conducive to divine encounter. This is particularly clear in the writing of Roman Catholic eco-feminist theologian Mary C. Grey in Beyond the Dark Night. ${ }^{37}$ Grey expresses her concern at the 'sinister' way in which the shopping centres of the Western world are 'mimicking the architecture of the emptying cathedrals in a kind of demonic parody'. ${ }^{38}$ Here nothing is authentic or profound but all is hollow and shallow, including what she describes in terms of a parody of the sacrament: the encounter at the cash till. ${ }^{39}$ While Grey has a point about the potential emotional emptiness of such places, there is a danger that such places are written off as irredeemably worldly, places where it would be unlikely if not impossible to encounter God.

Reinforcing this bias towards the natural, Grey's position as an eco-theologian becomes particularly evident in her discussion of the sacramental, located for her in encounters of the earthy Jesus among fishermen and in stories about sparrows, vineyards and bread-making. ${ }^{40}$ In her list of sacramental substances she names 'bread, wine, oil, salt, water, soil, trees, flowers, fruits of the earth'. ${ }^{41}$ Grey does discuss the urban origins of Christianity and contemporary urban contexts as places for mission. However, such contexts are for Grey intrinsically problematic, speaking most loudly of injustice, ecological exploitation and poverty, places which threaten to separate us further from rather than draw us closer to God. Yes, God may be found here, Grey argues, but in the guise of the Christ of social justice and suffering, not in possibilities for beauty and transcendence.

While my own love of nature makes me sympathetic towards the idea of the divine encountered through the natural world, I find Grey's view of the city troubling, as one who walks among the concrete, steel and glass of a post-war High Street, among high instances of addiction, rough sleeping and poverty. According to Grey, such a context could well demand a ministry dedicated only to social justice. While there are Christians engaged in such work in Southendon-Sea, the focus of my ministry is less upon the transformation of people's material circumstances and more about enabling moments of transcendence, 
resourcing poiēsis, and pointing to God in urban places rather than in spite of them. My identity as a presbyter, a minister of word and sacrament, is significant to the way in which my ministry has developed and is distinct from that of a deacon or Christian outreach worker.

\section{Drawing the lines}

What is clear from the work of Fiddes, Inge and Grey is that while understanding of the sacramental may be broad, there is a need to set some boundaries. Inge in particular recognises the potential problems that may follow from identifying all things as potentially sacramental and highlights the importance of relationship and response in order to offer a further criterion for sacrament. Quoting Macquarrie, 'For anything to become sacrament, something has to be contributed from both sides, ${ }^{\prime 2}$ Inge conceives sacrament as an action that must be initiated by God's grace and completed by the acceptance of that grace in the believer. In particular Inge emphasises the importance of the tradition of believers as the only context in which such encounters might be meaningful.

Taking the research of Hay and Morisy already cited, in which over half the respondents claim some kind of 'religious experience', it seems that Inge is limiting sacramental experience that leads somewhere to those with an understanding of the Christian tradition. He argues that churchgoing Christians may experience a sacramental encounter with God both inside and outside the church and its building; people outside the church community who do not have such a background or understanding cannot experience such sacramental encounter. Although he argues for 'a two-way interaction between what is experienced in church and what is experienced in the world', this is reserved for Christians with an understanding of Scripture and tradition. ${ }^{43}$

On this crucial issue of the relationship between experience, meaning and revelation, the influence of post-liberal Lutheran theologian George Lindbeck is worthy of exploration. Of particular interest are two of the models of belief Lindbeck examines in The Nature of Doctrine. ${ }^{44}$ The experiential-expressivist model places a 'common core experience' 45 at the heart of religion, and regardless of whether such experience is fully understood, all humans experience it. In this model, experience is the source of faith. However, Lindbeck ultimately argues in favour of a cultural-linguistic model in which the narratives and rituals of religion provide the framework for religious experience 
and are the only means through which such experience can be expressed. ${ }^{46}$ Without the context of the Christian story, provided by the Church through Scripture and its traditions, people cannot experience God because they cannot know that they have experienced God. Such arguments must prompt serious soul-searching for the Church in the light of a largely unchurched and dechurched population. The cultural-linguistic model gives the Church a unique mediating position in the relationship between God and humanity and places a significant burden of responsibility upon it to communicate effectively.

For an alternative view, which emphasises the value of bodily experience, I turn to Anglican professor of religious studies Douglas Davies, who draws on social anthropology in his work. In common with Fiddes, Inge and Grey, Davies cites the doctrine of the Incarnation as the foundation of a world-view in which all earthy matter is 'a potential vehicle for the divine., ${ }^{47}$ Understanding this as rooted in Catholic rather than Protestant theology, Davies argues that such sacramental understanding 'relates the sacred and the profane' such that nothing lies beyond the reach of the sacred. ${ }^{48}$ This he contrasts with the Protestant Lutheran understanding of two kingdoms divided and the consequent concept of conversion as the transition from the worldly kingdom to the heavenly. It is possible to see already that the exclusivist understandings of sacrament can be considered a construct of a particular way of thinking about God's relationship with the material world, dividing those who can and cannot experience the sacramental along the lines of those who are inside and outside the Church.

Davies goes on to explore the writing of influential Protestant theologian Paul Tillich, who he regards as dismissing ideas of two separate realms of existence in the ideal but accepting that religion often sets itself apart, creating notions of the sacred and secular. ${ }^{49}$ Davies describes Tillich's theology as 'existential', focused on human experience and being, from which stems a 'method of theology' that engages with 'life and experience ... in a way that sees involvement as a participation in God. ${ }^{50}$ It is possible to see something of the roots of Davies' central tenet in the work of Tillich, namely the importance of embodiment to both anthropology and theology. For Davies, embodiment is not simply another aspect of humanity which must be 'theologized'. In taking seriously the everyday embodied experiences of life, Davies is seeking to validate what he calls 'non-systematic faith', which he argues should not be considered subsidiary to systematic theology and which he understands as normal for most: 'ordinary believers are seldom guided and informed by systematic doctrines ... because ordinary life does not work in that way. ${ }^{\prime 51}$ 
A central theme of Davies' book is the relationship between embodiment and religion, and the way in which behaviour both expresses and consolidates our beliefs and values. 'Embodiment theory', he argues, prevents the 'oversystematizing' approach of traditional theology to religious belief..$^{52}$ This is significant not only because it means that what we think and believe is intrinsically linked to what we do, but also because it suggests we do not simply decide with our minds and perform with our bodies. Rather the flow is twoway: behaviour has the power to both 'enshrine and express belief at one and the same time'..$^{53}$ Returning to Inge's assertion that only those with prior knowledge of Christian tradition will further their relationship with God through a divine encounter, ${ }^{54}$ Davies' thought challenges this: 'embodiment questions the primacy of profile for formal doctrine when considering Christian spirituality and practice. In reality, spirituality is a behavioural endeavour, and people "become" Christian by behaving Christianly. ${ }^{55}$ While it may be going too far to suggest that those with no formal religious understanding can experience something explicitly sacramental through a religious experience, it is also going too far to suggest that a clear line can be drawn between those who will and those who will not be able to experience God.

Davies' ideas about ritual have an impact not only upon the question of who may experience the sacramental but also on the question of what form this experience may take. Ritual is of particular importance to the Christian religion, argues Davies, because it has a particular ritual at its heart: the Eucharist. However, Davies goes on to express doubts about the role of the Church and its representatives in effectively mediating and controlling what is understood by Christians engaging in religious ritual. He acknowledges the theological tradition in which ritual is viewed as expression of doctrine yet he favours recent developments in ritual theory which regard it as a discrete phenomenon. ${ }^{56}$ In exploring the notion of ritual as either a language to be decoded or 'non-language phenomena', ${ }^{57}$ Davies opts for the latter, regarding ritual as 'an end in itself' rather than a language. ${ }^{58}$ This has implications for the relationship between ritual and meaning, with a distinction being made between propositional meaning - relating ritual to language and the expression of ideas, and meaning as emotion - satisfaction from actions as meaning. Davies thus expresses caution at the over-intellectualising of ritual in favour of its ordinariness. His conclusion is important in relation to those who experienced and participated in the 'Easter Icons' installation as it becomes possible to understand their participation in a ritual act as a possible means to experiencing the divine for those with no prior knowledge of the rite itself. 
Ewan Kelly, a pastoral theologian who also draws upon social anthropology, concurs with this view that part of the power and importance of ritual, for people of faith and no faith, is found both in its rootedness in the ordinary and its enabling of a whole-body experience as an end in itself. ${ }^{59}$ Writing about constructing funeral rites for newborn babies in the context of hospital chaplaincy, Kelly understands ritual as a way of relating to self, others and God that engages every part of us: 'there may be physical action, stimulation of our imagination and feelings, a stirring of our spirit, senses and sexuality as well as intellectual engagement. ${ }^{\prime 60}$ In common with Davies, Kelly understands ritual as more than an outward expression of intellectual understanding, beliefs and values; he conceives human existence as a complex intertwining of the physical and the intellectual, the material and the abstract. Also in common with Davies, Kelly regards ritual as both expressing and creating meaning, exploring the way in which ritual is a part of and gives meaning to everyday experiences, from the deliberately ordered rituals of religion to the ordinary rituals of a family meal. ${ }^{61}$ It is possible to draw parallels between this understanding of ritual and Fiddes' understanding of sacrament in what might be described as a paradox of the ordinary and the extraordinary in both phenomena. Indeed, just as the question is asked, 'When does something potentially sacramental become sacrament?' Kelly asks, 'When does ritual-like activity actually become ritual?' 62

\section{Conclusion}

This conceptualisation of ritual as relating to the ordinary and mundane aspects of life is significant to my sense of needing to 'demystify' the ritual of the Eucharist among the people for whom I am a minister of word and sacrament. Here I return to the installation with which I began. The invitation to all to share in bread and grape juice at the shopping centre was a means of enabling people to participate in a sacrament-like ritual and to share in the story of Jesus, an opportunity for me to minister word and sacrament beyond the'language barrier' between the traditions of my faith and the people among whom I minister. Reflecting on the last meal Jesus shared with his friends, it is the locus for much of what has been explored in this article: the sacramental, the importance of embodiment, the material and the everyday as a means of experiencing the divine, and the role of ritual in faith and life.

Taking the shared experience of embodiment seen through the lens of the Incarnation as a starting point, this article has explored approaches which value 
the sacramental and do not confine it to Christians attending eucharistic services. Rather, they allow for sacramental encounters in all of life and in all places. However, even within this broad understanding of what is sacramental there remains a desire to set boundaries and limitations among those writing from a primarily theological perspective. These boundaries are formed by the prioritisation of church tradition over human experience and based upon assumptions about the relationship between understanding and behaviour. Alternative interpretations from a social anthropology perspective do not subordinate experience to understanding but rather recognise the dynamic flow between the two and thus do not seek to limit experience of God to prior knowledge. Further dialogue between theology and anthropology on the nature of meaning-making and religious experience may bear much fruit for a Church seeking the common ground to communicate with those we have yet to reach.

\section{Notes}

1. Southend-on-Sea is a large seaside town on the south-east coast of England.

2. While the bread and grape juice used for the installation were not consecrated, they were used as a deliberate reference to the sacrament of the Eucharist. The Methodist Church recognises two dominical sacraments: Baptism and Eucharist, though the term 'sacramental' may be understood much more broadly.

3. Brierley Consultancy 2014.

4. Office for National Statistics 2012.

5. Brierley Consultancy 2014.

6. The Methodist Church 2014.

7. Bauman 2000, p. 10.

8. Bauman 2000, p. 1.

9. Bauman 2000, p. 7.

10. The Message paraphrase of the Bible renders the description of the Incarnation in John 1.14 as 'The Word became flesh and blood, and moved into the neighbourhood.'

11. Wesley 1967, p. 139.

12. Heidegger 1975, cited in Inge 2003, p. 13.

13. Inge 2003, p. 13.

14. Inge 2003.

15. Inge 2003, p. 18.

16. Inge 2003, p. 5.

17. Frost 2014, p. 11.

18. Walton 2014, p. 13.

19. Walton 2014, p. 15.

20. Walton 2014, p. 13.

21. Fiddes 2000. 
22. Fiddes 2000, pp. 278-279.

23. Fiddes 2000, p. 280.

24. Fiddes 2000, p. 281.

25. Fiddes 2000, p. 289.

26. Fiddes 2000, p. 294.

27. Fiddes 2000, p.294.

28. Inge 2003.

29. Schillibeeckx 1963, cited in Inge 2003, p. 60.

30. Inge 2003, p. 60.

31. Inge 2003, p. 60.

32. Inge 2003, p. 63.

33. Inge 2003, p. 67.

34. Gorringe 1989, cited in Inge 2003, p. 67.

35. Inge 2003, p. 70-71.

36. Inge 2003, p. 72.

37. Grey 1997.

38. Grey 1997, p. 24.

39. Grey 1997, p. 25.

40. Grey 1997, p. 66.

41. Grey 1997, p. 65.

42. Macquarrie 1997, cited in Inge 2003, p. 80.

43. Inge 2003, p. 80.

44. Lindbeck 1984.

45. Lindbeck 1984, p. 31.

46. Lindbeck 1984, p. 37.

47. Davies 2002, p. 11.

48. Davies 2002, p. 11.

49. Davies 2002, p. 11.

50. Davies 2002, p. 14.

51. Davies 2002, p. 21.

52. Davies 2002, p. 41.

53. Davies 2002, p. 41.

54. Inge 2003, p. 81.

55. Davies 2002, p. 42.

56. Davies 2002, p. 112.

57. Davies 2002, p. 112.

58. Davies 2002, p. 113.

59. Kelly 2002.

60. Kelly 2002, p. 4.

61. Kelly 2002, p. 5.

62. Kelly 2002, p. 6. 


\section{Bibliography}

Bauman, D. 2000. Liquid Modernity. Cambridge: Polity Press.

Davies, D. 2002. Anthropology and Theology. Oxford: Berg.

Fiddes, P. 2000. Participating in God: A Pastoral Doctrine of the Trinity. London: Darton, Longman \& Todd.

Frost, M. 2014. Incarnate: The Body of Christ in an Age of Disengagement. Downers Grove, IL: InterVarsity Press.

Grey, M. 1997. Beyond the Dark Night: A Way Forward for the Church? London: Cassell. Hodgson, P. and King, R. 2008. Christian Theology: An Introduction to its Traditions and Tasks. London: SPCK.

Inge, J. 2003. A Christian Theology of Place. Farnham: Ashgate.

Kelly, E. 2002. 'Marking Life and Death', Contact 12: 3-39.

Lindbeck, G. 1984. The Nature of Doctrine: Religion and Theology in a Postliberal Age. Philadelphia, PA: The Westminster Press.

Pattison, S. and Lynch, G. 'Pastoral and Practical Theology' in Ford, D. (ed.). 1997. The Modern Theologians. Oxford: Blackwell.

Peterson, E. 2003. The Message: Remix 2.0. Colorado Springs, CO: NavPress.

Walton, H. 2014. 'Seeking Wisdom in Practical Theology: Phronesis, Poetics and Everyday Life', Practical Theology 7(1) (March): 5-18.

Wesley, J. 1967. Journal. London: Epworth Press.

\section{Websites}

Brierley Consultancy Survey. 2014. UK Christianity 2005-2015. Available at http://www. brierleyconsultancy.com/images/csintro.pdf (accessed 19 April 2015).

The Methodist Church. 2014. Statistics for Mission, Conference report. Available at http://www.methodistconference.org.uk/media/228157/conf-2014-37-statisticsfor-mission.pdf (accessed 19 April 2015).

Office for National Statistics. 2012. 2011 Census. Available at http://www.ons.gov.uk/ ons/rel/census/2011-census/key-statistics-for-local-authorities-in-england-andwales/rpt-religion.html (accessed 19 April 2015). 